\title{
Crowding out in a Dual Currency Regime? Digital versus Fiat Currency
}

\author{
KiHoon Hong ${ }^{*}$, Kyounghoon Park ${ }^{* *}$, Jongmin $\mathrm{Yu}^{* * *}$
}

The views expressed herein are those of the authors and do not necessarily reflect the official views of the Bank of Korea. When reporting or citing this paper, the authors' names should always be explicitly stated.

* Assistant Professor, College of Business, Hongik University, E-mail: hong.jimmy@gmail.com

** Economist, Economic Research Institute, The Bank of Korea, Tel: +82-880-5481,

E-mail: pkhoon@bok.or.kr

*** Corresponding author. Assistant Professor, School of Economics, Hongik University,

E-mail: yucono@hongik.ac.kr

The authors are grateful to Daeyoung Jeong, Jong Ku Kang, Yunmi Nam, and an anonymous referee, and participants in the seminar at the Bank of Korea for their helpful comments. 


\section{Contents}

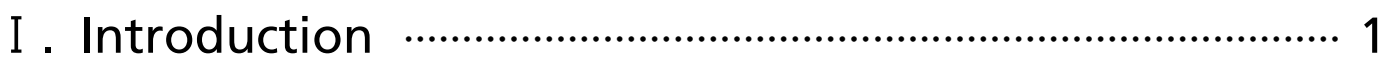

II. Related Literature and Background ….......................... 5

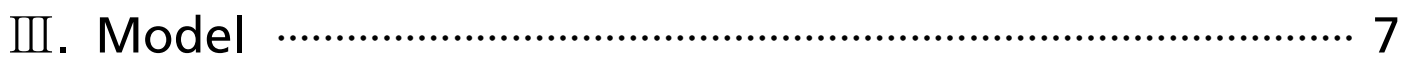

IV. Numerical Examples and Implications …….................. 22

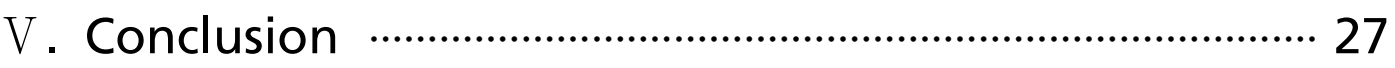

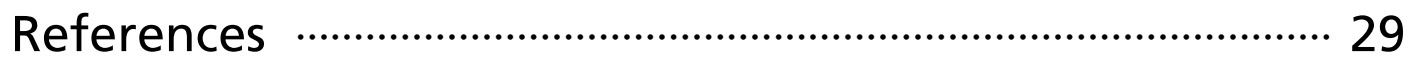

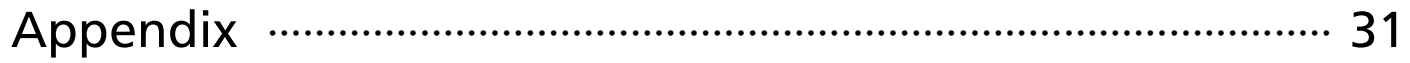




\section{Crowding out in a Dual Currency Regime? Digital versus Fiat Currency}

In this paper, we analyse a dual currency regime with fiat currency and digital currency and investigate potential crowding-out effects of fiat currency or digital currency under the framework of the traditional monetary economic model. We find that crowding out only occurs under extreme assumptions, i.e. extremely high costs associated with the use (medium of exchange and store of value) of one currency and extremely low costs associated with the use of the other currency.

Keywords: Bitcoin, Digital currency, Dual currency, Crowding out

JEL Classification: E00, E41, E42 


\section{I . Introduction}

The sudden rise of Bitcoin and many other cryptocurrencies has attracted much interest in digital currencies. Apparently, there are many studies related to the computer science technology of Bitcoin (Narayanan et al., 2016). Indeed, much of the interest and research regarding digital currencies has been limited to its technology, blockchain, and not expanded into research on monetary economics although cryptocurrencies are often classified as a currency. Many of the analyses on cryptocurrency conducted by social science researchers have been descriptive (Böhme et al., 2015). Some researchers are interested in governance and regulatory concerns but only from a legal perspective (Chuen, 2015).

However, the rise of cryptocurrencies could have significant impact on our monetary system as they are privately issued currencies, thus not regulated by central banks. Fortunately, there are some studies such as Saito (2015) and Fernández-Villaverde (2016) that investigate the potential competition between privately issued digital currencies. However, we find that most of the existing research employs a very complicated model of advanced monetary economics; thus they are very sophisticated to understand. Therefore, in this paper, we examine the impact of privately issued digital currency and fiat currency using the simplest framework, with which we may derive the most straightforward implications. More specifically, we attempt to answer the question of whether digital currency will crowd out fiat currency.

The contribution of this paper is twofold. First, this is one of the first studies directly investigating the crowding-out of fiat currency when a privately issued digital currency exists. Second, this paper employs the simplest model of monetary economics, as well as the minimum number of assumptions. Therefore it draws straightforward implications. We believe that the simplicity and brevity of our model add value to the existing literature while sophisticated models have their own merits. The result of our paper can be useful to policy makers and regulators who want to have insights in the new monetary system where a privately issued digital currency coexists with a central bank issued fiat currency. 
An economy with two currencies where the two are freely used by the market participants of the economy is referred to as a dual currency regime, which is often observed in emerging economies with dollarization. In some developing countries where foreign currency is officially used, it is often not easy to incentivize market participants to hold a domestic currency. Such economy is called, a 'partially dollarized economy' where a foreign currency is demanded not only as a store of value but as a means of exchange. This is commonly known as transaction dollarization or currency substitution.

Historically, there are many examples of dual or multiple currency economies. There have been various commodity currencies as the media of exchange including shells, cigarettes, cocoa beans, barley among many others. ${ }^{1)}$ In the Middle Ages, gold, silver and copper coins were often circulated simultaneously at predefined exchange rates. In the 1800 s, commodity-backed money was circulated as well as government-issued fiat currency. In the U.S., multiple currencies were common as the media of exchange during the 1930s. Then privately-issued banknotes were used simultaneously with government-backed fiat and commodity-backed currencies. More recently, numerous examples of dual currency economies are observed in developing and emerging economies including Liberia, Cuba and many other Latin American states. Switzerland is the example of an advanced industrial country where the foreign currency euro is accepted in most parts despite the global acceptance of the Swiss franc.

Previously existing dual currency regimes can be classified into two types: a regime with a commodity-backed and a government-issued fiat currencies; and a regime with two different government-issued fiat currencies. Commodity-backed currencies derive their values from underlying commodities while government-issued fiat currencies are backed by the taxation power of the government (see also Selgin, 2015).

However, the recent emergence of digital currency opens up a new type of dual currency regime in which digital currency2), which has no intrinsic value

1) An example (Cigarette Money) is analyzed by Burdett, Trejos and Wright (2001).

2) There might be two types of digital currencies, which are privately-issued and central-bank-issued one. In 
and a government-issued fiat currency coexist. One of the well-known examples of privately-issued digital currencies is Bitcoin. Digital currency is an internet-based medium of exchange different from physical currencies (i.e., bills and coins) while representing properties similar to physical ones. However, it allows immediate transactions and borderless transfer-of-ownership. Both virtual currency and encrypted currency are digital money types, but the opposite is incorrect. As with traditional currency, virtual currency can be used to purchase physical goods and services, but their use may be limited to specific communities such as online games or social networks. We assume that digital money, which shows a large increase in versatility as in the case of Bitcoin, would have more versatility than legal ones in the future. However, in real usage, digital currency is very diverse and various in terms of whether it has a fixed value or whether it is intended for investment. The generality of digital currency is also significantly lower than that of legal one. Also, digital money is limited to the case where investment is possible because digital money is not only an exchange means such as Bitcoin, but also variable in value.

One of the problems incurred by the dual currency regime may be the potential crowding-out effect of fiat currency by digital currency. This issue motivates our research. When there are multiple currencies in a single economy, according to Gresham's law, the circulation process of money, consisting of "good" money and "bad" money, is quickly dominated by "bad" money if both currencies are accepted as equal values (see Bernholz and Gersbach, 1992). Here, good money is defined as money that shows a similar value with a real one. This is usually stated as "Bad money drives out good."

On the other hand, Rolnick and Weber (1986) theoretically investigate the possibility that bad money would value a good money with a premium instead of pushing it out of circulation. Although Rolnick and Weber (1986) ignore the

our paper, we focus on the former. See Barrdear and Kumhof (2016) and BIS (2015) for more detailed descriptions on the central-bank-issued digital currency. Recently central banks, such as Bank of England, People's Bank of China, Bank of Canada, Reserve Bank of Australia, Bank of Russia, De Nederlandsche Bank, and BIS (2015) argue the necessity of central-bank-issued digital currency based on distributed ledger technology in order to deal with the issues related to the shrinking role of central banks in dual currency regime. 
influence of legal tender legislation which requires people to accept both good and bad money as if they were of equal value, the experience of dollarization in countries with a weak economy3) and currency may be seen as Gresham's Law operates in its reverse form. Such dollarization experience seems to support the findings of Rolnick and Weber (1986) since during dollarization the dollar was not legal tender generally; in some cases its use was illegal (see Guidotti and Rodriguez, 1992). Mundell (1998) also explains that in general or rather in the long-run, the inverse holds, i.e. that strong or good currencies drive out bad currencies.

More recent research regarding a dual currency regime has focused on analysing extreme cases, either complete dollarization or an economy with only domestic currency (see Chang and Velasco, 2001; Cooley and Quadrini, 2001; Schmitt-Grohe and Uribe, 2001). Previous research on dual currency regimes indicates that one currency could crowd out the other when two currencies are used simultaneously in one economy. In this study, we analyse a dual currency regime with fiat currency and digital currency, and investigate the potential crowding-out effects of fiat currency by digital currency, or vice versa, under the framework of the traditional monetary economic model. We define the crowding-out of currency as a phenomenon where one currency becomes completely out of use due to the preference for another currency.

As previously discussed, we intend to investigate the crowding-out effect in a dual currency regime where two currencies, a fiat and a digital, are circulated.4) We find that crowding out only occurs under extreme assumptions: extremely high cost associated with the use (medium of exchange and store of value) of one currency and extremely low cost associated with the use of the other. Based on the result of our analysis, we suggest some implications for future research on the economic effect of the increased use of digital currency and on the related policy.

3) In order to reduce the cost of dollarization, the central bank of Equador introduced the Electronic Money System based on the centralized virtual account in the central bank in 2015 .

4) One of the major goals of this paper is to investigate whether one currency could potentially crowd out another. Therefore we do not make any assumption regarding crowding-out effect and leave it to be discovered from the theoretical findings. 
The remainder of the paper is divided into following sections. Section 2 explains the research background and related literature. Section 3 presents the theoretical model, derives closed-form solutions and discusses theoretical implications of a potential crowding-out effect. Section 4 shows numeric examples to give intuitions about our analytic solutions, followed by the summary of main findings and concluding remarks in Section 5.

\section{Related Literature and Background}

First, this paper builds upon the literature on the search-theoretic approach. Kiyotaki and Wright (1993) (hereafter KW (1993)) is the first generation of the search-theoretic approach to monetary economics, and Trejos and Wright (1995) and Lagos and Wright (2005) are the second and the third, respectively. The objective of this paper is straightforward: we analyse a dual currency regime with fiat currency and digital currency, and then investigate the potential crowding-out effects of fiat or digital currencies under the framework of the traditional monetary economic model. In order to achieve this goal, we need to employ a model of money. There are three generations of models: the first generation model assumes one unit of good and one unit of money; the second generation model expands the first generation model by assuming endogenous prices; and the third generation model expands the second generation model by assuming endogenous prices and goods.

Our research question is simple enough, and we do not find any reason to create and track endogenous distribution of money. We also note that one of the most remarkable aspects of this study is to provide insights under the simplest framework as possible. Therefore we consider the third generation model not to be efficient for our purpose as it could make the analysis very complicated. The second generation model assumes that goods are divisible. Again, while this could be very effective and therefore could have a significant implication to our analysis, this is not within the scope of our primary research objective. For the brevity and the simplicity of the analysis, we decide to employ 
the simplest and most straightforward model, the first generation model, which will allow us to achieve our goal. However, we also notice that expanding our result with the second generation model could be an interesting topic for further research.

Next, this paper is related to a small strand of literature on the economy of digital currency and its effect on the monetary policy. Saito (2015) extends Trejos and Wright (1995) to a dual currency model and allows new entrants who observe market performance of each currency for the previous period. He introduces stable and unstable equilibria and shows that the equilibrium moves towards unstable if the inflation rate of traditional money decreases, which implies the failure of Bitcoin. Extending the model of Lagos and Wright (2005), Fernández-Villaverde and Sanches (2016) build a theoretical framework for private digital currencies. They show that a privately-issued digital currency might be driven out of the economy when there is no productive capital, while it stays with productive capital.

Barrdear and Kumhof (2016), on the other hand, explore another theoretical framework of central-bank-issued digital currency without private digital currency. They adopt a bank-based DSGE model following Benes and Kumhof (2012) and Jakab and Kumhof (2015), and embed a central bank digital currency (CBDC). Their model shows that introducing the CBDC could enhance economic growth by reducing a real interest rate, distortionary taxes, and monetary transaction costs. BIS (2015) analyses the main aspects relating to the development of digital currencies. They point out the distributed ledger technology as a main innovative element of digital currencies and suggest some implications for central banks and payment system.

Although there exist implied results, most of the previous studies do not explicitly analyse whether there is the crowding-out effect between digital currency and fiat currency. Furthermore, existing studies employ the third generation model of monetary economics, which makes their analyses very complicated. In this respect, our study contributes to the literature by extending one of the simplest models, KW (1993). We believe that simplicity is very important as long as we could derive relevant implications. Our model closely 
follows that of KW (1993) with some modifications in order to investigate the dual currency regime created by digital and fiat currencies. Our analysis starts from the last section (Section IV) of KW (1993) where they investigate the possibility of multiple fiat money. They state that their motivation is "the observation that, in some economies, there seems to be more than one type of currency in simultaneous circulation. For instance, it is possible in certain locations to have both a domestic currency and a foreign currency used in exchange, although perhaps the former is generally acceptable while the latter is only partially acceptable. One example is that Canadian dollars are often accepted just across the U.S. border, and vice versa, although the foreign currencies are not always accepted by domestic residents. Furthermore, this situation can persist even if the two currencies differ in terms of rates of return or other intrinsic properties. 5 )"

\section{Model}

\section{Digital Currency}

Digital currency is defined as an internet-based medium of exchange different from physical ones (e.g., banknotes and coins) that exhibits properties of currencies, but allows for immediate transactions and transfer of ownership across borders. Virtual currency and cryptocurrencies are both digital currency types. As with traditional currencies, these currencies can be used to purchase physical goods and services, but may be limited to specific communities, such as online games or social networks. Digital currencies came to the market from the 1990s Dot-com bubble. One of the first services is the Liberty Reserve founded in 2006, which is known as a digital call service. Users can convert dollars or euros into Liberty Reserve dollars or Liberty Reserve euros and exchange these digital currencies easily at a $1 \%$ fee. $Q$ coins or QQ coins were introduced in

5) Kiyotaki and Wright (1993), p.74. 
early 2005 as a sort of commodity-based digital currency on the Tencent QQ messaging platform. The $Q$ coin has been effective in China and had an unstable impact on the Chinese renminbi. A recent attention to cryptocurrencies has increased an interest in digital currencies, along with Bitcoin which was introduced in 2009 and now becomes the most widely used digital currency.

According to the European Central Bank's "Virtual currency schemes - a further analysis" report of February 2015, virtual currency is a digital value that is not issued by a central bank, a credit institution, or an electronic money system, and can sometimes be used as an alternative to money. In the report of October 2012, the European Central Bank defines virtual currency as a type of non-regulated digital money that is issued and generally controlled by developers, and used and approved by certain virtual community members.

According to the "Digital Currency" report of the Bank for International Settlements in November 2015, digital currencies are assets that are displayed in digital format and have some monetary characteristics. Digital money can be designated as sovereign currency and issued by an issuer responsible for using digital money in cash. In this case, digital currency represents electronic money. Digital currency, denominated in its value unit or with decentralized or automatic issuance, is considered virtual currency. Bitcoin is therefore not only a digital currency, but also a virtual currency because Bitcoin and its alternatives are based on encryption algorithms. These virtual currencies are also known as Crypto Money.

In this research, we limit the scope of a digital currency to a privately issued decentralized digital currency such as Bitcoin. We also limit the scope of fiat currency to cash holdings, excluding any digitalized fiat currency such as a credit card or online banking since these payment methods are located somewhere between a traditional fiat currency and digital currency. They cannot be classified as digital currency in our analysis because they are not privately issued. In order to make a clear distinction between a digital currency and a fiat currency, we narrow the definition of fiat currency to cash holdings.

A digital currency and a fiat currency are very different in many aspects. 1) A 
digital currency is based on a sophisticated technology which may require users to adopt. This can be very important to market participants who are not willing to (or cannot) adopt such technology. We can think of individuals who are reluctant to use smartphones and stick to the old technology. 2) Users of digital currency can be (or could believe that they are) exposed to security risk of their personal information. 3) Use of digital currency is highly likely to require registration of the ownership. 4) Digital currency seems to be more universally accepted due to its convenience.

Based on the differences above, we can consider various reasons why individuals may or may not prefer a privately issued digital currency to a fiat currency. Individuals may like to use a digital currency for the following reasons. 1) Preference for new technology: People who like to adopt new technology could be the earliest digital currency adopters. 2) Faster transactions: Digital currency, in general, is known to provide a faster transaction speed. 3) Universal use: Digital currency is more likely to be accepted universally without border limitations. 4) Less or no shoe leather cost: Digital currency is cheaper to own, carry and spend. 5) Ownership registration: As previously discussed, a digital currency is likely to require registration of ownership. Individuals may like this for security purposes. These reasons can make the use of fiat currency more costly in terms of utility, thus promoting the use of digital currency.

On the other hand, there are many reasons why individual may like to use fiat currency. 1) Anonymity: As previously discussed, a digital currency may require registration of ownership. Individuals are usually reluctant to reveal themselves in an exchange market. Some people may prefer anonymity due to personal information security reasons or tax issues. There could be traders who do not want to reveal their exchange patterns. 2) Reluctance of adopting new technology: Some people may not be able to digest technology that a digital currency is based on. 3) Government regulations: There could be certain specialized products that government regulates to be traded only with a central bank issued fiat currency. These products possibly include military supplies purchased by government or goods of strategically important industries. There 
are infinite reasons why a market participant may like or may not like a privately issued digital currency. We can see reasons why someone does not use a smartphone despite its popularity. Such reasons can make the use of digital currency more costly in terms of utility.

From this perspective, we can rationally reason that there is a group of individuals who do not want to use a digital currency while most of market participants prefer the use. Therefore, under the assumption that privately issued digital currency exists, it is rational to consider that some goods are traded only with fiat currency while most goods are traded with digital currency. Hence, in building a model of this economy, it is reasonable to assume that there are two types of goods: one is less popular and traded only with fiat currency; the other is more popular and traded with digital currency.

\section{The Dual Currency Regime Model}

As previously stated, our analysis starts from the last section of KW (1993). In order to study the phenomenon of dual currency equilibria, KW (1993) assume that there are two types of fiat money represented by two different colors, red and blue. So as to simplify the presentation, they only consider the case in which specialization is exogenous and assume that both types of money are indivisible. In this paper, we set up as follows: time is continuous; the number of participants is normalized to 1, consistent with KW (1993); two currencies exist in the economy, a fiat currency and a digital currency. As already discussed in Section 3.1, there are many reasons why an agent prefers one currency to another: intrinsic value and anonymity for fiat currency; and ease of payment (e.g., via a smartphone) and transaction speed for digital currency. Consistent with KW (1993), we also employ a parameter $x$, with $0<x<1$, which captures the extent to which real commodity and taste are differentiated. Readers can refer to KW $(1993)^{6)}$ for the further explanation of the parameter $x$.

Parting from KW (1993), we introduce heterogeneity in agents' utility

6) “ $x$ equals the proportion of commodities that can be consumed by any given agent, and $x$ also equals the proportion of agents that can consume any given commodity," KW (1993), p.64. 
function and let $c_{i}$ be the subjective cost of an agent $i$ using fiat money over digital currency. The cost, $c_{i}$, could be positive or negative, and represents the net cost and benefit of using fiat money. Therefore if $c_{i}$ is positive, agent $i$ considers using fiat money to be costly despite the benefits that the agent may receive. If $c_{i}$ is negative, the benefit outweighs the cost of using fiat currency. Factors that increase $c_{i}$ can include the convenience of digital currency, pursuit of new technology (e.g., "early adopter" preferences), preference for a decentralized currency or financial and monetary system, high inflation, rising confidence in digital currency as a medium of exchange and many others. The cost variable, $c_{i}$, can also be influenced by currency user preferences. For example, if someone is very reluctant to adopt online payment system due to a security concern, $c_{i}$ may take a negative value.

As previously discussed, there are many reasons why digital currency may or may not be preferred over fiat currency. Although we have identified and investigated some reasons in Section 3.1., such reasons are subjective and highly likely to vary among market participants. Therefore we believe that identifying such reasons is out of the scope of this research and the distribution of $c_{i}$ is assumed to be exogenous. This particular assumption should not be considered too strong as it is regarding market participants' preferences. We, however, also believe that endogenous $c_{i}$ could be an interesting topic for further research. The cumulative probability distribution $F\left(c_{i}\right)$ is known to all market participants. As illustrated in Figure 1, we assume two types of commodities, $S$ and $G$ in a market. Good $S$ is exchanged via fiat currency only while good $G$ is exchanged via digital currency only. We assume that $S$ is a special good and $G$ is a normal good. 
Figure 1: Flow Chart

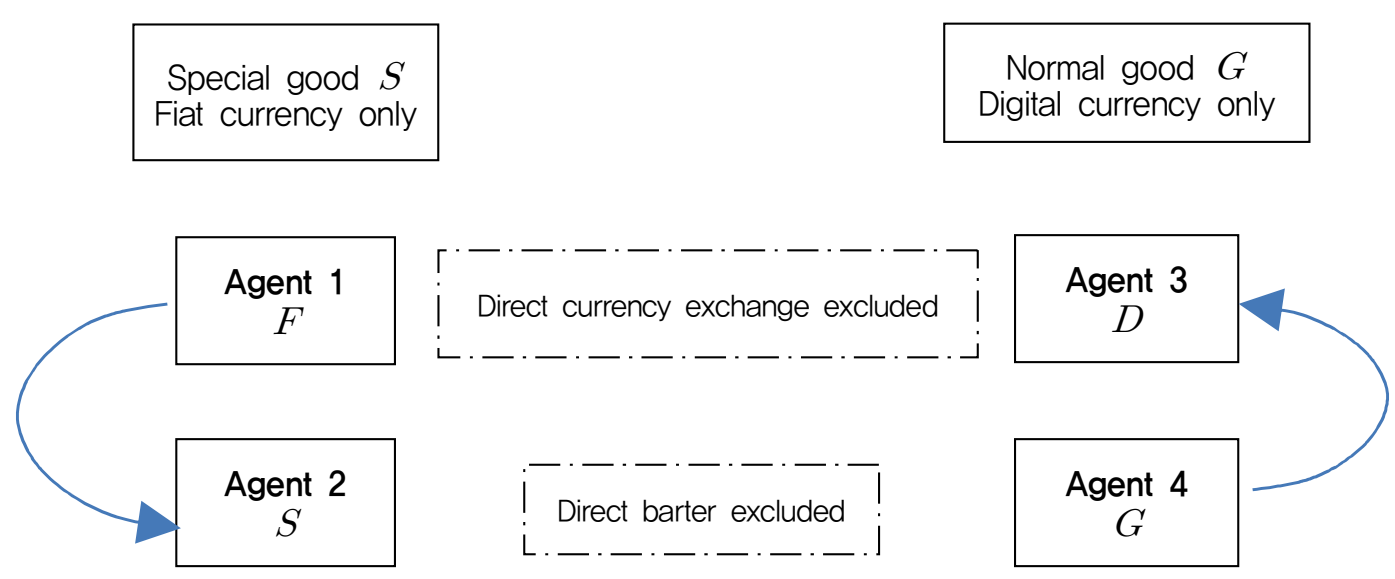

The reasons that a special good, $S$, is defined as a good that can only be exchanged with fiat currency $F$ are due to government regulations or seller's special situations; normal goods can be exchanged with digital currency $D . c_{i}$ is determined by the currency users, while $S$ is determined by good suppliers or government regulations. As discussed in Section 3.1., there are many reasons why good providers want to receive fiat currency in a transaction, such as preference for anonymity, tax purpose or personal information security concerns. Hiding transaction patterns could be another. The seller may not have adopted the technology that digital currency is based on. Whatever the reason, an important implication is that there will be some goods that are traded only with fiat currency. We classify such goods into one category and refer as a special good, $S$.

In modelling the exchange economy between market participants, we assume that agents cannot consume the goods that they are endowed with. This indicates that if an agent is endowed with a good, the agent must meet another agent and trade with him/her. The meeting occurs on a random basis and we exclude a possibility of barter. This assumption is consistent with KW (1993). We remind our readers that the primary objective of our analysis is to investigate the use of currencies only, which is dependent on the agent's consumption function. Therefore we exclude any analysis of production side in this paper, in order to keep the brevity of the research. The equilibrium in the current 
research implies an equilibrium between the demands for digital and fiat currencies and can be considered Pareto optimal where no market participants have any incentive to switch the use of currency that they have chosen. Incorporating analysis of the production side and pursuing a general equilibrium may be very interesting research topics. We will limit the scope of our analysis to the demand side only and leave such investigation of general equilibrium to potential future researchers.

\section{Consumption Function}

The total number of agents is normalized to 1 . The parameter, $\alpha$, indicates the fraction of the agents selecting to trade $S$ with $F$. The fraction of the agents selecting to trade $G$ with $D$ is $1-\alpha$. In our analysis, the parameter $\alpha$ determines the individual choice of preferred goods and is assumed to be exogenous. Then fiat currency $F$ is randomly allocated among $\alpha$ fraction of the agents, and digital currency $D$ is randomly allocated among $1-\alpha$ fraction of the agents, accordingly. The measure of agents endowed with fiat currency distributed in the market is denoted as $M_{f}$ while the measure of agents endowed with digital currency distributed in the market is denoted as $M_{d}$. We assume that fiat currency is issued by a central bank, and therefore its supply is controlled by and limited to one country. However digital currency is privately issued and borderless. In order to have a realistic model, we assume $M_{f}<M_{d}$. The relative fraction of the two currencies with respect to the fraction of market participants, $m_{f}$ and $m_{d}$ can be written as $m_{f}=\frac{M_{f}}{\alpha}$ and $m_{d}=\frac{M_{d}}{1-\alpha}$. We also assume that all goods and currencies are indivisible. Thus, an agent could own one unit of good $S$ or $G$, or one unit of currency $F$ or $D$. Consequently, we have $M_{f}+M_{d}+S+G=1, M_{f}+S=\alpha$ and $M_{d}+G=1-\alpha$.

The relative supply is the ratio of $m_{f}$ and $m_{d}$. The exchange rate is not used in the model, therefore, we do not need to derive it. However we want to note that the exchange rate is determined by the relative supply of and the relative demand for the two currencies. The parameters, $m_{f}$ and $m_{d}$, can be interpreted 
as the normalized relative amount of the two currencies, and therefore, we have $m_{f}+m_{d}<1 . M_{f}, M_{d}, G$ and $S$ are the absolute supplies of fiat currency, digital currency, normal good and special good while $m_{f}$ and $m_{d}$ are the relative supplies of fiat and digital currencies, respectively.

Agents randomly meet and try to trade; the probability of matching is denoted by $\lambda$. Exchange can only happen when one agent with a currency and another with a commodity are randomly matched, and a buyer likes what a seller can offer. As previously discussed, this probability is denoted as $x$, which captures the extent to which real commodity and taste are differentiated. More specifically, it is the proportion of commodities consumed by any given agent. If a transaction occurs, a buyer consumes an exchanged good, and a seller receives a currency and then seeks a good he/she demands via a random matching process. The production cost is assumed to be zero following KW (1993).

When a special good $S$ is consumed (with fiat currency only), an individual receives a certain level of utility, $u>0$, while consuming currency yields zero utility. However consuming a unit of $S$ also incurs a cost of $c_{i}$ as previously assumed. When a normal good $G$ is consumed, the level of utility that an individual can enjoy is proportionate to $c_{i}$, i.e. the larger the cost of consuming $S$, the larger the utility of consuming the normal good $G$. Therefore the utility functions of consuming good $S$ and $G$ can be written as:

$$
u_{S}(i)=u-c_{i} \text { and } u_{G}(i)=c_{i}
$$

We assume the utility functions of the simplest form in order to avoid any unnecessary complication. The relative demands for fiat and digital currencies, $m d_{F}$ and $m d_{D}$, depend on the level of these utilities. As previously discussed, our model closely follows that of KW (1993). However, we also deviate from KW (1993) in some aspects. Table 1 summarizes the differences between our model and that of KW (1993) in order to clearly indicate the differences, and thereby, to help readers to have better understandings. 
Table 1: Comparison to KW (1993)

\begin{tabular}{|c|c|c|}
\hline & KW (1993) & This Paper \\
\hline Agent & $\begin{array}{l}\text { Large number of infinite-lived agent } \\
\text { normalized to } 1\end{array}$ & $\begin{array}{l}\text { Large number of infinite-lived agent } \\
\text { normalized to } 1\end{array}$ \\
\hline Goods & $\begin{array}{l}\text { Large number of consumption goods, } \\
\text { indivisible and units of size one }\end{array}$ & $\begin{array}{l}\text { Large number of consumption goods, } \\
\text { indivisible and units of size one, but } \\
\text { two types of goods }(S, G)\end{array}$ \\
\hline Money & $\begin{array}{l}\text { - no intrinsic value } \\
\text { - indivisible }\end{array}$ & $\begin{array}{l}\text { - no intrinsic value } \\
\text { - indivisible }\end{array}$ \\
\hline $\begin{array}{l}\text { Endowment } \\
\text { (Money and } \\
\text { commodity supply) }\end{array}$ & $\begin{array}{l}\text { [Baseline] } \\
-M \text { of agent : money } \\
-1-M \text { of agent : real commodity } \\
\text { [Section IV] } \\
\text { - Red money } \\
\text { - Blue money } \\
\text { - Real commodity } \\
\text { Absolute supply : } M_{R}, M_{B} \\
M_{R}+M_{B}<1 \\
\text { Relative supply: } \mu_{R}, \mu_{B} \\
\text { Portion of traders with real commodities } \\
\mu_{C}=1-\mu_{R}-\mu_{B}\end{array}$ & $\begin{array}{l}S: \text { special goods } \\
G: \text { normal goods } \\
D: \text { digital currency } \\
F: \text { fiat currency } \\
\text { Absolute supply : } M_{F}, M_{D}, S, G \\
\text { Relative supply: } m_{f}, m_{d} \\
m_{f}+m_{d}<1\end{array}$ \\
\hline$x$ & $\begin{array}{l}\text { - portion/percentage of commodities } \\
\text { consumable by any given agent }\end{array}$ & $\begin{array}{l}\text { - portion/percentage of commodities } \\
\text { consumable by any given agent }\end{array}$ \\
\hline Utility function & $\begin{array}{l}-u>0 \text { with consumption good } \\
-u=0 \text { with money }\end{array}$ & $\begin{array}{l}-u>0 \text { with consumption good } \\
-u=0 \text { with money }\end{array}$ \\
\hline Cost & $-\varepsilon$ transaction cost & $\begin{array}{l}\text { - no transaction cost } \\
-c_{i} \text { heterogeneous subjective and } \\
\text { exogenous cost for consuming } S \\
\text { good with fiat currency }\end{array}$ \\
\hline $\begin{array}{l}\text { Production } \\
\text { technology }\end{array}$ & $\begin{array}{l}\text { - Two inputs: i) consumption good, ii) a } \\
\text { random amount of time } \\
\text { - a constant arrival rate } \alpha \text { according to } \\
\text { a Poisson process } \rightarrow \text { average output } \\
\text { per unit time }\end{array}$ & $\begin{array}{l}\text { The production cost is assumed to be } \\
\text { zero }\end{array}$ \\
\hline Traders' meeting & Constant arrival rate $\beta$ & Constant arrival rate $\lambda$ \\
\hline $\begin{array}{l}\text { Best-response } \\
\text { problem }\end{array}$ & $\pi$ & $\begin{array}{l}\text { The best response problem is beyond } \\
\text { the scope of this paper. }\end{array}$ \\
\hline
\end{tabular}




\section{Value Function}

The model of KW (1993) normalizes the unit of goods to 1, which is different from the current model. The Bellman's equations can be written as

$$
\begin{aligned}
& r V_{S}^{f}\left(c_{i}\right)=\lambda\left(1-m_{f}\right) x\left(u_{S}(i)+V_{S}^{g}\left(c_{i}\right)-V_{S}^{f}\left(c_{i}\right)\right) \\
& r V_{S}^{g}\left(c_{i}\right)=\lambda m_{f} x\left(V_{S}^{f}\left(c_{i}\right)-V_{S}^{g}\left(c_{i}\right)\right) \\
& r V_{G}^{d}\left(c_{i}\right)=\lambda\left(1-m_{d}\right) x\left(u_{G}(i)+V_{G}^{g}\left(c_{i}\right)-V_{G}^{d}\left(c_{i}\right)\right) \\
& r V_{G}^{g}\left(c_{i}\right)=\lambda m_{d} x\left(V_{G}^{d}\left(c_{i}\right)-V_{G}^{g}\left(c_{i}\right)\right)
\end{aligned}
$$

where $r>0$ is the rate of the time preference. $V_{S}^{f}\left(c_{i}\right)$ is the value function where an individual $i$ owns fiat money; $V_{S}^{g}\left(c_{i}\right)$ is the value function where an individual $i$ owns good $S$. The LHS of Eq.(2), $r V_{S}^{f}\left(c_{i}\right)$, is the value obtained at every moment of owning fiat currency. Digital currency may depreciate in its relative value as it does not pay interest. Either way, the actual return of the two currencies should be the same. If not, relative demand will force them to be equal. The RHS of the Eq.(2) implies that an agent $i$ will meet someone with the probability (which is implied by $\lambda$ ), and if a counterpart of agent $i$ holds a unit of good $S$ (which is implied by $1-m_{f}$ ) and the agent $i$ likes the commodity $S$ owned by the counterpart (which is implied by the probability of $x$ ), then a transaction will take place. If a transaction occurs, the agent $i$ obtains utility $u_{S}(i)$ from consuming the good $S$. The agent $i$ shifts from a currency holder to a consumer; and the value function changes by $V_{S}^{g}\left(c_{i}\right)-V_{S}^{f}\left(c_{i}\right)$. The LHS of the Eq.(3), $r V_{S}^{g}\left(c_{i}\right)$, is the value function for an agent who owns the good $S$.

Similarly, the Bellman's equations of trading good $G$ can be written as Eq.(4) and Eq.(5). The LHS of the Eq.(4), $r V_{G}^{d}\left(c_{i}\right)$, is the value obtained at every moment of owning digital currency. The LHS of the Eq.(5), $r V_{G}^{g}\left(c_{i}\right)$, is the value function for an agent who owns the good $G$. Implications of Eq.(4) is similar to that of Eq.(2). The only difference is that the good consumed is $G$, instead of $S$; the term $1-m_{d}$, instead of $1-m_{f}$. 


\section{The Equilibrium}

It is clear that the expected values that can be achieved via trading either good $S$ with fiat currency $F$ or trading good $G$ with digital currency $D$ can be written as follows.

$$
\begin{aligned}
& E\left[V_{S}\left(c_{i}\right)\right]=m_{f} V_{S}^{f}\left(c_{i}\right)+\left(1-m_{f}\right) V_{S}^{g}\left(c_{i}\right) \\
& E\left[V_{G}\left(c_{i}\right)\right]=m_{d} V_{G}^{d}\left(c_{i}\right)+\left(1-m_{d}\right) V_{G}^{g}\left(c_{i}\right)
\end{aligned}
$$

These can be rewritten as

$$
\begin{aligned}
& E\left[V_{S}\left(c_{i}\right)\right]=m_{f}\left(1-m_{f}\right) \lambda u_{S}(i) / r \\
& E\left[V_{G}\left(c_{i}\right)\right]=m_{d}\left(1-m_{d}\right) \lambda u_{G}(i) / r
\end{aligned}
$$

Substituting with the Eq.(1), the Eq.(8) and (9) becomes

$$
\begin{aligned}
& E\left[V_{S}\left(c_{i}\right)\right]=m_{f}\left(1-m_{f}\right) \lambda\left(u-c_{i}\right) / r \\
& E\left[V_{G}\left(c_{i}\right)\right]=m_{d}\left(1-m_{d}\right) \lambda c_{i} / r
\end{aligned}
$$

The relative expected value from trading $S$ with fiat currency to the value from trading $G$ with digital currency can be written as $E\left[V_{S}\left(c_{i}\right)\right] / E\left[V_{G}\left(c_{i}\right)\right]$. By fixing this relative value as a constant $\Phi$, we can derive a critical cost for an individual agent, which makes an agent indifference in using the fiat currency or the digital currency.

$$
\frac{E\left[V_{S}\left(c_{i}\right)\right]}{E\left[V_{G}\left(c_{i}\right)\right]}=\frac{m_{f}\left(1-m_{f}\right) u_{S}(i)}{m_{d}\left(1-m_{d}\right) u_{G}(i)}=\frac{m_{f}\left(1-m_{f}\right)}{m_{d}\left(1-m_{d}\right)} \frac{u-c_{i}}{c_{i}}=\Phi
$$

The relative value in Eq.(12) can be decomposed into two components. The first component, $\frac{m_{f}\left(1-m_{f}\right)}{m_{d}\left(1-m_{d}\right)}$, implies that the relative size of $m_{f}$ and $m_{d}$ can alter the level of the relative expected value of selecting different currencies. 
The second component, $\frac{u-c_{i}}{c_{i}}$, implies that the expected value in each market depends on the relative cost of the two currencies. Many of the previous studies on the potential impact of privately issued digital currencies, focus on the emergence of a new type of currency, which is represented by the first term of the Eq.(12). However, Eq.(12) indicates that subjective utility and the cost of using digital currency are also important factors in determining the relationship between digital and fiat currencies, and therefore regarded as our first finding. Our first theoretical finding should be intuitive and rationally make sense.

Since participants who trade $S$ can only use fiat currency as a medium of exchange, the level of the expected utility is directly related to the demand for fiat currency. When trading good $G$, only digital currency can be employed as a medium of exchange. Therefore the expected utility from the trading of good $G$ is related to the demand for digital currency. Assuming the effects of a unit expected utility on the demand for fiat and digital currencies are identical, the relative demand for fiat and digital currencies can be expressed as

$$
\begin{aligned}
m d_{F} & =\frac{E\left[V_{S}\left(c_{i}\right)\right]}{E\left[V_{S}\left(c_{i}\right)\right]+E\left[V_{G}\left(c_{i}\right)\right]} \\
m d_{D} & =\frac{E\left[V_{G}\left(c_{i}\right)\right]}{E\left[V_{S}\left(c_{i}\right)\right]+E\left[V_{G}\left(c_{i}\right)\right]}
\end{aligned}
$$

From Eq.(13) and (14), we can derive the relative money demand for fiat and digital currencies.

\section{Proposition 1:}

$$
\begin{aligned}
m d_{F} & =\frac{m_{f}\left(1-m_{f}\right) u-m_{f}\left(1-m_{f}\right) \bar{c}}{m_{f}\left(1-m_{f}\right) u+\left[m_{d}\left(1-m_{d}\right)-m_{f}\left(1-m_{f}\right)\right] \bar{c}} \\
m d_{D} & =\frac{m_{d}\left(1-m_{d}\right) \bar{c}}{m_{f}\left(1-m_{f}\right) u+\left[m_{d}\left(1-m_{d}\right)-m_{f}\left(1-m_{f}\right)\right] \bar{c}}
\end{aligned}
$$


where $\bar{c}$ is the expected value of $c_{i}$. This indicates that the relative demand for fiat and digital currencies is dependent on the average of heterogeneous costs in the economy. The proof of Proposition 1 is included in Appendix 1. Proposition 1 implies that the relative demand for both fiat and digital currencies is independent of the probability of market participants being matched, $\lambda$, and the time preference. However the relative demand for both currencies is dependent on the relative supply of the currencies and the heterogeneous cost of the currencies to market participants, which represents the demand side of the two currencies. This is consistent with the consumption theory: the budget line is determined by the production function and uniformly applied to all market participants while the demand is determined by the utility function (which are heterogeneous) of the participants. We can observe a similar frame in the thoughts of the Capital Asset Pricing Theory: the efficient frontier is provided by the available set of risky securities in an economy and applied to all market participant; however the equilibrium portfolio of individual investors is dependent on individual utility functions.

\section{Proposition 2:}

$$
\frac{\partial m d_{F}}{\partial \bar{c}}<0 \text { and } \frac{\partial m d_{D}}{\partial \bar{c}}>0
$$

The proof of Proposition 2 is included in Appendix 2. Proposition 2 indicates that the fiat currency demand is negatively related to $\bar{c}$ while the digital currency demand is positively related to $\bar{c}$. This finding is consistent with our expectations. The most important implication that can be drawn from Proposition 2 is that digital currency and fiat currency do not automatically and necessarily crowd-out each other. Additionally, we can think of a case where the use of money (fiat or digital) always incurs a cost and the cost is not perfectly known to an agent while including some level of uncertainty. In this case, a full crowding-out is not likely to happen since the uncertainty regarding the cost distribution always leaves some possibilities that using one currency may provide a higher expected utility. 
In order to derive the expected critical cost, which determines whether the representative agent will trade good $S$ or $G$, Eq. (12) can be rewritten as

$$
\lambda\left(m_{d}\left(1-m_{d}\right) \Phi+m_{f}\left(1-m_{f}\right)\right) \bar{c}=m_{f}\left(1-m_{f}\right) \lambda u
$$

Therefore we can derive the critical cost.

Proposition 3: The critical cost, $c^{*}$ can be written as follows.

$$
c^{*}=\frac{m_{f}\left(1-m_{f}\right)}{\Phi m_{d}\left(1-m_{d}\right)+m_{f}\left(1-m_{f}\right)}
$$

Derivation of Proposition 3 is omitted as it is an immediate case of Eq.(18). Note that the critical cost $c^{*}$ is the level of cost that makes the two currencies indifferent. This cost is related to the ratio of the relative money supply of the two currencies and determined by the utility function. From the analytic solution in equation (17), we derive the relationship as below.

Proposition 4: The sensitivity of the critical cost, $c^{*}$ with respect to the relative money supplies can be written as follows.

$$
\frac{\partial c^{*}}{\partial m_{f}}>0 \text { and } \frac{\partial c^{*}}{\partial m_{d}}<0
$$

The proof of Proposition 4 is omitted. The critical cost positively depends on the relative money supply of fiat money and negatively depends on the supply of digital money. This is because $c^{*}$ is considered to be the cost of using fiat money. If we flip the definition, the sign of the derivatives will be flipped as well. We can also conclude that the critical cost is not extremely high or low to crowd out the other currency since the two currencies are actually used together. 


\section{Robustness of the Model with respect to $\alpha$}

The parameter $\alpha$ that determines whether the representative agent trades good $S$ or $G$ is assumed to be exogenous in our model. This parameter represents the average tendency of agents in trading $S$ or $G$. Therefore, rationally speaking, the parameter could be dependent on the average cost of using fiat currency, $\bar{c}$. If $\bar{c}$ is relatively high, $\alpha$ would be relatively low; if $\bar{c}$ is relatively low, $\alpha$ would be relatively high. Thus, $\alpha$ can be modelled endogenously. Our original assumption of exogeneity of $\alpha$ is associated with one of our primary objectives, providing the simplest model as long as it does not alter the main findings. Therefore the model is robust to $\alpha$ 's endogeneity, and we intend to show this robustness in this section.

Assume that $\alpha=\alpha(\bar{c})$. Then we have $\frac{\partial \alpha}{\partial \bar{c}}<0$. The sensitivity of $\alpha$ is negative as we discussed at the start of this section.7)

Let $T=m_{f}\left(1-m_{f}\right) u+\left[m_{d}\left(1-m_{d}\right)-m_{f}\left(1-m_{f}\right)\right] \bar{c}=m_{f}\left(1-m_{f}\right)(u-\bar{c})+m_{d}\left(1-m_{d}\right) \bar{c}$ and $Q=m_{f}\left(1-m_{f}\right)(u-\bar{c}), A=m_{d}\left(1-m_{d}\right) \bar{c}$.

Then

$$
\begin{gathered}
\frac{\partial T}{\partial \alpha}=\frac{\partial Q}{\partial \alpha}+\frac{\partial A}{\partial \alpha} \\
\frac{\partial m d_{F}}{\partial \alpha}=\frac{\frac{\partial Q}{\partial \alpha} T-Q \frac{\partial T}{\partial \alpha}}{T^{2}}=\frac{\frac{\partial Q}{\partial \alpha}(Q+A)-Q\left(\frac{\partial Q}{\partial \alpha}+\frac{\partial A}{\partial \alpha}\right)}{T^{2}}=\frac{\frac{\partial Q}{\partial \alpha} A-Q \frac{\partial A}{\partial \alpha}}{T^{2}}
\end{gathered}
$$

Since $M_{f}=\alpha-S$ and $M_{d}=1-\alpha-G$, we have $\frac{\partial m d_{F}}{\partial \alpha}>0$. Therefore

$$
\frac{\partial m d_{F}}{\partial \bar{c}}=\frac{\partial m d_{F}}{\partial \alpha} \frac{\partial \alpha}{\partial \bar{c}}<0
$$

7) In order to secure the robustness of the analysis, an endogenous case is described as a function of the cost. However, in addition to the heterogeneity of economic subjects, average subjective costs can be formed by economic structure and social system, and reflected as critical cost. 
Consequently, assuming the parameter $\alpha$ to be endogenous does not alter the main result. For the brevity of the paper, we assumed that the parameter is exogenous.

\section{Numerical Examples and Implications}

In this section, we try numerical analysis to see the properties of parameters in the analytic solutions driven from the previous sections. We need to make assumptions about parameter values to get nuanced predictions of analytic solutions from the model of how the rest of other parameters affect objective solutions. Table 2 assumes the value of parameters at default. When a certain parameter is a control variable, we assume an interval around the default value in Table 2 for the control variable.

Table 2: Parameters used in the model

\begin{tabular}{l|l}
\hline \multicolumn{1}{c|}{ Parameter } & Value \\
\hline Amount of fiat currency, $M_{f}$ & 0.3 \\
\hline Amount of digital currency, $M_{d}$ & 0.4 \\
\hline Level of utility when a special good $S$ is consumed, $u$ & 100 \\
\hline Portion of agents selecting to trade $S$ with $F, \alpha$ & 0.5 \\
\hline Relative expected value of selecting to trade $S$ with $F$ to selecting to trade $G$ with $D, \Phi$ & 1 \\
\hline
\end{tabular}

The level of the expected utilities of agents selecting to trade $S$ with fiat currency and to trade $G$ with digital currency, $E\left[V_{S}\left(c_{i}\right)\right]$ and $E\left[V_{G}\left(c_{i}\right)\right]$, represents the demand for the currencies that can be used as a medium of exchange in the two trades.

Figure 2 illustrates the relative money demand based on the assumed parameters in Table 2. The figure shows the demand for fiat currency decreases as the cost $(\bar{c})$ increases, whereas the demand for digital currency increases as the cost increases as we assumed in the model. 
Figure 2: Relative Money Demand

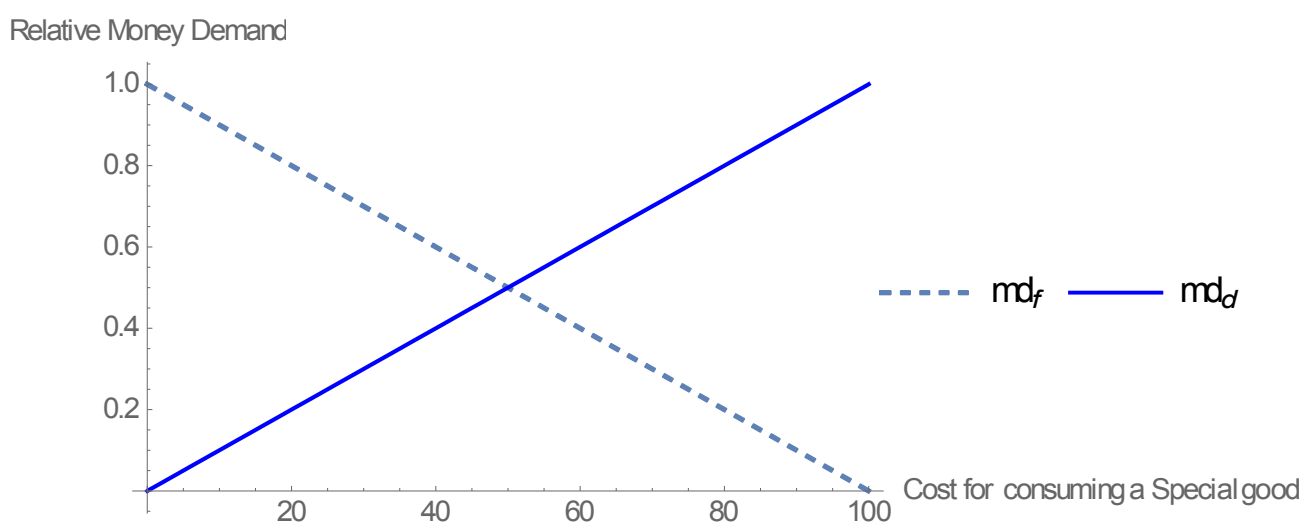

$\frac{\partial m d_{F}}{\partial \bar{c}}<0$ and $\frac{\partial m d_{D}}{\partial \bar{c}}>0$

Note we can derive the level of cost that makes the two currencies indifferent. This clearly shows that one currency does not need to crowd-out the other unless the perceived cost of fiat money or digital money has an extreme value. We can also conclude that the fact that the two currencies are actually used together argues that the critical cost is not extremely high or low to crowd the other currency.

Since the demand for a certain currency can also be interpreted as a marginal value, this figure describes not only the effect of the critical cost but also the effect of voluntary value changes in both currencies. Even if the cost of consuming a special good does not change, any change in the money demand can shift the demand curve, leading to changes in the level of critical cost. For instance, if fiat currency suffers from high inflation and thus loses its value, the demand for digital currency may increase; or the level of critical cost that decides the usage of both currencies may decrease. Similarly, if digital currency loses its value, the minimum level of preference for digital currency will 
Figure 3: Relative money demand when the portion of each trade changes

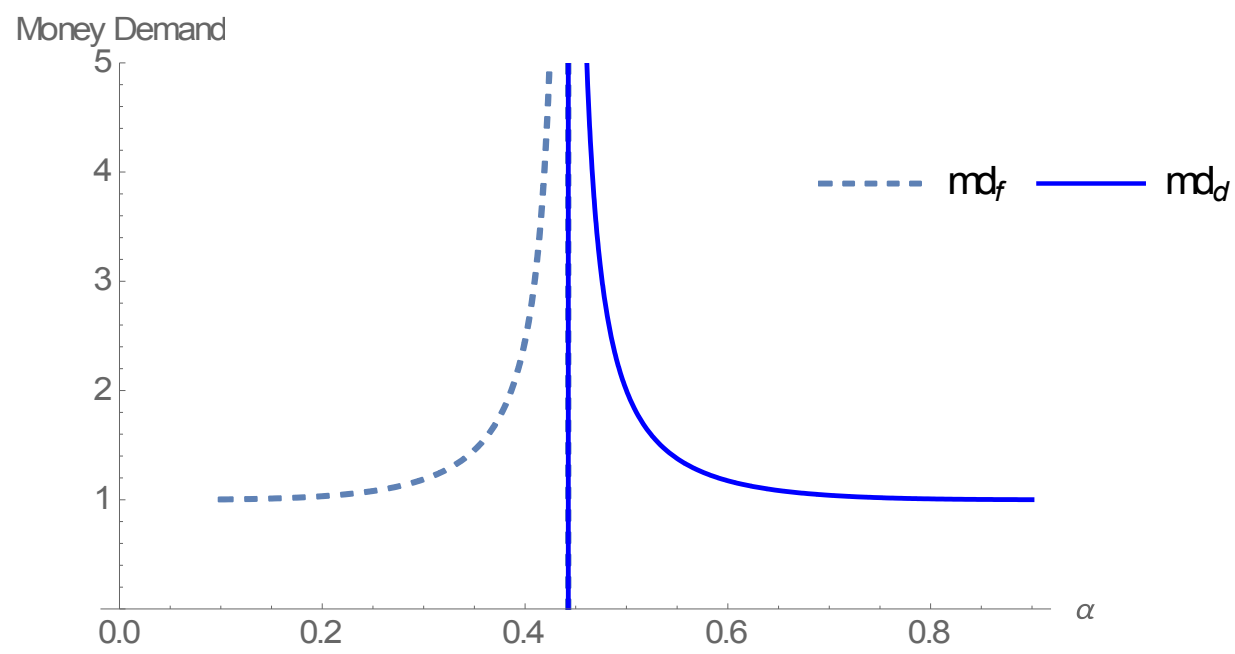

increase, and eventually fiat currency will crowd-out digital currency. However, if the use of money (commodity, fiat or digital) always incurs a cost and if the cost is not perfectly known to the agents and includes some level of uncertainty, a full crowding-out is less likely.

Importantly, the eventual fixed supply of Bitcoin has incurred a deflationary bias with increasing prices for a long time, and this could lead to the crowding-out of fiat currency as a store of value but not necessarily as a medium of exchange. In fact, a higher price of Bitcoin can deter agents to use it as a medium of exchange and rather store it for future consumption as demonstrated in many exchanges for years.

Figure 3 shows the effect of the portion of agents, $\alpha$, selecting to trade $S$ with only fiat currency. The relative demand is determined by $\alpha$, whereas, it is independent of $\lambda$ and $r$. This figure intuitively shows that each demand is defined distinctively as the portion of agents selecting to trade $S$ changes. When the portion of agents to trade $S$ increases, the demand for fiat currency increases steeply up to a certain threshold. This is straightforward because agents can trade $S$ only with fiat currency. However, once too many ones choose to trade $S$, the demand for the fiat drops to 0 since the use of fiat currency becomes costly; on the other hand, the demand for the digital goes to infinity. 
Figure 4: Relationship between the critical cost and the relative value of special goods

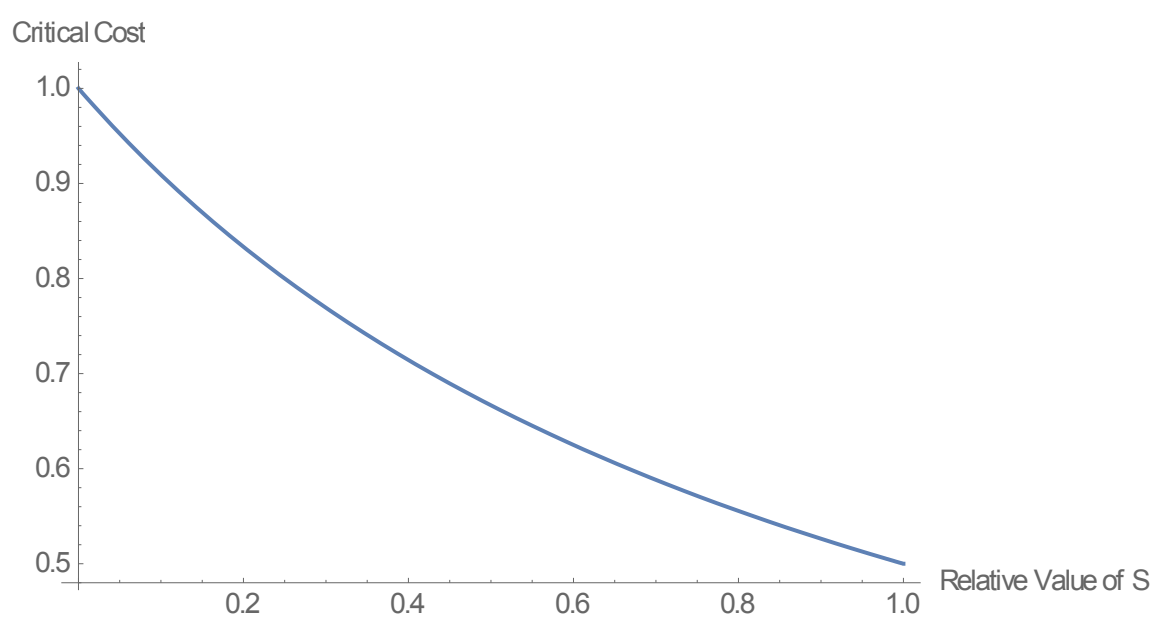

Likewise, when the portion of agents to trade $G, 1-\alpha$, increases, the demand for digital currency surges to a certain threshold, which is also easy to predict because agents can trade $G$ with the digital currency.

In Figure 4, we can also check the effect of the relative expected value from trading $S$ with fiat currency to the value from trading $G$ with digital currency, $\Phi$, on the critical cost level, $c^{*}$. The analytic solution indicates that the initial endowment of $S$ and $G$ is an important key factor. The figure illustrates the relation among the variables; as the relative expected value from trading $S$ with fiat currency increases, the critical cost decreases. This illustration corresponds to the result from the Figure 2 since the parallel upside shift of the relative value of fiat currency increases the critical cost, and vice versa. The value of $S$, a commodity that can be bought with fiat currency, is of course influenced by the usefulness of digital currency, such as the convenience of use. In this figure, we describe how the relative value of two goods responds to the absolute level of the critical cost intuitively.

The panel A of Figure 5 highlights the simultaneous effects of cost and utility on the relative fiat money demand. The aggregate level of utility is defined as a certain level of utility, $u$, when a special good $S$ is consumed with fiat currency only, while consuming currency yields zero utility. The figure 
Figure 5: Effect of cost and utility

Panel A) Effect on the relative fiat money demand

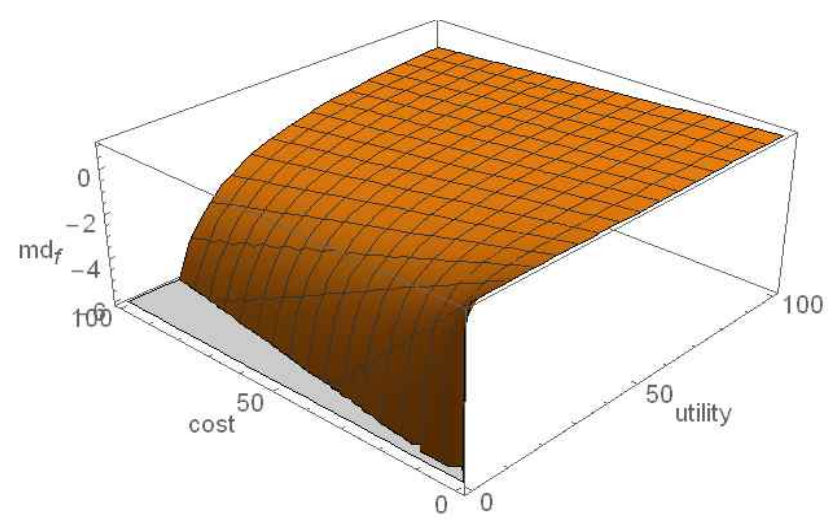

Panel B) Effect on the relative digital money demand

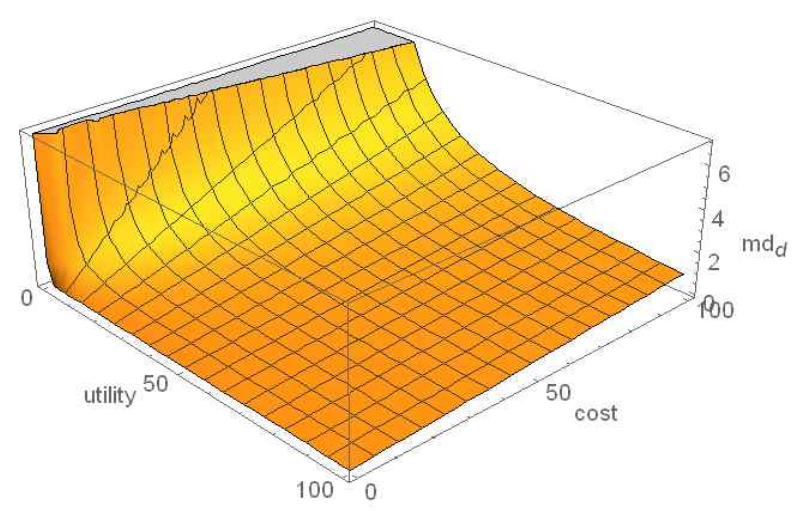

shows the required level of utility raises the demand for fiat currency, which is straightforward, and the cost for using fiat currency reduces the level of the fiat currency demand. The panel B of Figure 5 illustrates the opposite case of the demand for digital currency because an increase in utility for fiat currency may crowd out the use of digital currency whereas the cost for using fiat currency may alternatively increase the use of digital currency. 


\section{Conclusion}

We show the relationship between the use of fiat currency and that of digital currency. High costs of using fiat currency increase the demand for digital currency. Similarly, high costs of using digital currency relative to fiat currency raise the demand for fiat currency. In a world of imperfect currencies with uncertain costs associated with the use of a currency, it is unlikely that the relative costs of using digital currency will be low enough to drive out and accordingly crowd out fiat currency entirely. Our results rather suggest that the threshold of equating the demand for fiat currency with that for digital currency will allow the co-existence of both currencies. As long as the exchange rates between fiat and digital currencies are not fixed, Gresham's law cannot be applied in its correct form since it is unclear which one will be "bad" and which one will be "good." However, a continuous decrease in the value of fiat currency has been historically clear due to price inflation or, more recently, monetary policy such as "quantitative easing." This is in stark contrast to the predetermined growth path and eventual fixed supply of Bitcoin which implies a deflationary bias. This could lead to a situation in which Bitcoin drives out fiat currency as a store of value. However, security or trust issues - the decentralization of digital currency and the absence of insurance provided by governmental authorities - may prevent digital currency from being used as a store of value. Instead, digital currency may be used as a medium of exchange dominantly.

Future research can analyse, both theoretically and empirically, how digital currencies change the degree of specialization and globalization when the overall supply of money increases as new forms of money do not completely substitute for each other. Most of the studies on currency competition are theoretical analysis including this paper. If data are available, however, empirical analysis of such currency competition should be carried out importantly. Further, we may attempt to extend our model to a triple currency regime with private-issued digital currency, central-bank-issued digital currency and fiat currency. For instance, many central banks including the Bank of 
England are discussing the potential issuance of digital currencies. This attempt could drastically change our monetary system. With the possibility of 'death of cash' and the rise of digital currencies (such as Bitcoin), there are strong arguments that central banks should start issuing "digital cash" - an electronic version of notes and coins. The Bank of England has already posed a question about the potential digital cash, or 'central bank digital currency,' prompted by an ongoing rise of electronic payment means and the emergence of alternative currencies such as Bitcoin. In particular, monetary policy instruments are expected to have different impact on the cost of using money, as mutually-structured money coexists. Therefore, in future research, it is necessary to examine how monetary policy will affect the direction and the speed of changes in the demand elasticity of money, directly or indirectly.

In addition, the value of digital currencies may not be fixed in the legal system and may be devalued, resulting in shoe leather costs. This topic has not been explored yet in the context of digital money which has been appreciated by the ever-increasing demand. Thus, it can be also one of the topics for future research. 


\section{References}

Bank of International Settlement (2015), "Digital Currencies," Committee on Payments and Market Infrastructures.

Barrdear, J. and M. Kumhof (2016), "The Macroeconomics of Central Bank Issued Digital Currencies," Bank of England Staff Working Paper No. 605.

Benes, J. and M. Kumhof (2012), "The Chicago Plan Revisited," IMF Working Paper WP/12/202.

Bernholz, P. and H. Gersbach (1992), "Gresham's Law: Theory," The New Palgrave Dictionary of Money and Finance, Macmillan: London and Basingstoke, Vol. 2, pp. 286-288.

Böhme, R., N. Christin, B. Edelman, and T. Moore (2015): "Bitcoin: Economics, Technology, and Governance," Journal of Economic Perspectives, Vol. 29(2), pp. 213-238.

Burdett, K., A. Trejos and R. Wright (2001), "Cigarette Money," Journal of Economic Theory, Vol. 99, pp. 117-142.

Chang, R. and A. Velasco (2001), "Dollarization: Analytical Issues," Harvard University, mimeo.

Chuen, D. L. K. (2015), Handbook of Digital Currency: Bitcoin, Innovation, Financial Instruments, and Big Data, Elsevier.

Cooley, T. and V. Quadrini (2001), "The Cost of Losing Monetary Independence: The Case of Mexico," Journal of Money, Credit and Banking, Vol. 33(2), pp. 370-397.

European Central Bank (2012), "Virtual Currency Schemes," "Virtual Currency Schemes - A Further Analysis."

Fernández-Villaverde, J. and D. Sanches (2016), "Can Currency Competition Work?," NBER Working Paper No. 22157.

Guidotti, P. E., and C. A. Rodriguez (1992), "Dollarization in Latin America Gresham law in reverse," International Monetary Fund Staff Papers, Vol. 39, pp. 518-544. 
Jakab, Z. and M. Kumhof (2015), "Banks Are Not Intermediaries of Loanable Funds - And Why This Matters," Bank of England Staff Working Papers No. 529.

Kiyotaki, N. and R. Wright (1989), "On Money as a Medium of Exchange," Journal of Political Economy, Vol. 97(4), pp. 927-954.

Kiyotaki, N. and R. Wright (1993), "A Search-Theoretic Approach to Monetary Economics," The American Economic Review, Vol. 83(1), pp. 63-77.

Lagos, R. and R. Wright (2003), "Dynamics, Cycles, and Sunspot Equilibria in Genuinely Dynamic, Fundamentally Disaggregative Models of Money," Journal of Economic Theory, Vol. 109(2), pp. 423-453.

Lagos, R. and R. Wright (2005), "A Unified Framework for Monetary Theory and Policy Analysis," Journal of Political Economy, Vol. 113(3), pp. 463-484.

Mundell, R. (1998), “Uses and Abuses of Gresham's Law in the History of Money," Zagreb Journal of Economics, Vol. 2(2), pp. 3-38.

Narayanan, A., J. Bonneau, E. Felten, A. Miller, and S. Goldfeder (2016), Bitcoin and Cryptocurrency Technologies, Princeton University Press.

Rolnick, A. J. and W. E. Weber (1986), "Gresham's Law or Gresham's Fallacy," Journal of Political Economy, Vol. 94(1), pp. 185-199.

Saito, T. (2015), "Bitcoin: A Search-Theoretic Approach," International Journal of Innovation in the Digital Economy, Vol. 6(2), pp. 52-71.

Schmitt-Grohe, S. and M. Uribe (2001), "Stabilization Policy and the Costs of Dollarization," Journal of Money Credit and Banking, Vol. 33(2), pp. 482509.

Selgin, G. (2003), “Gresham's Law," EH.Net Encyclopedia, edited by Robert Whaples, http://eh.net/encyclopedia/greshams-law/

Selgin, G. (2015), "Synthetic Commodity Money," Journal of Financial Stability, Vol. 17, pp. 92-99.

Trejos, A. and R. Wright (1995), "Search, Bargaining, Money, and Prices," Journal of Political Economy, Vol. 103(1), pp. 118-141. 


\section{Appendix}

\section{Appendix 1: Derivation of Proposition 1}

Since $E\left[V_{A}\left(c_{i}\right)\right]=m_{f}\left(1-m_{f}\right) \lambda\left(u-c_{i}\right) / r$ and $E\left[V_{B}\left(c_{i}\right)\right]=m_{d}\left(1-m_{d}\right) \lambda c_{i} / r$,

$$
\begin{aligned}
m d_{F} & =\frac{\left[m_{f}\left(1-m_{f}\right) \lambda(u-\bar{c}) / r\right]}{\left[m_{f}\left(1-m_{f}\right) \lambda(u-\bar{c}) / r\right]+\left[m_{d}\left(1-m_{d}\right) \lambda \bar{c} / r\right]} \\
m d_{D} & =\frac{\left[m_{d}\left(1-m_{d}\right) \lambda \bar{c} / r\right]}{\left[m_{f}\left(1-m_{f}\right) \lambda(u-\bar{c}) / r\right]+\left[m_{d}\left(1-m_{d}\right) \lambda \bar{c} / r\right]}
\end{aligned}
$$

These can be simplified as

$$
\begin{aligned}
m d_{F} & =\frac{m_{f}\left(1-m_{f}\right) u-m_{f}\left(1-m_{f}\right) \bar{c}}{m_{f}\left(1-m_{f}\right) u+\left[m_{d}\left(1-m_{d}\right)-m_{f}\left(1-m_{f}\right)\right] \bar{c}} \\
m d_{D} & =\frac{m_{d}\left(1-m_{d}\right) \bar{c}}{m_{f}\left(1-m_{f}\right) u+\left[m_{d}\left(1-m_{d}\right)-m_{f}\left(1-m_{f}\right)\right] \bar{c}}
\end{aligned}
$$

Note that $m d_{F}+m d_{D}=1$.

\section{Appendix 2: Derivation of Proposition 2}

(i) if $\bar{c}>0$

We note that $m_{f}\left(1-m_{f}\right) u-m_{f}\left(1-m_{f}\right) \bar{c}>0$ and $m_{d}\left(1-m_{d}\right) \bar{c}>0$

Let $T=m_{f}\left(1-m_{f}\right) u-m_{f}\left(1-m_{f}\right) \bar{c}+m_{d}\left(1-m_{d}\right) \bar{c}$

$=m_{f}\left(1-m_{f}\right) u+\left[m_{d}\left(1-m_{d}\right)-m_{f}\left(1-m_{f}\right)\right] \bar{c}>0$

$\frac{\partial T}{\partial \bar{c}}=m_{d}\left(1-m_{d}\right)-m_{f}\left(1-m_{f}\right)$

We also note that $m_{d}-m_{f}>0$ and $m_{d}\left(1-m_{d}\right)-m_{f}\left(1-m_{f}\right)=\left(m_{d}-m_{f}\right)\left(1-m_{f}-m_{d}\right)>0$ 
Then we have

$$
\frac{\partial m d_{F}}{\partial \bar{c}}=\frac{-m_{f}\left(1-m_{f}\right) T-m_{f}\left(1-m_{f}\right)(u-\bar{c}) \frac{\partial T}{\partial \bar{c}}}{T^{2}}
$$

The first term of the numerator:

$$
-m_{f}\left(1-m_{f}\right) T<0
$$

The second term of the numerator:

$$
\begin{aligned}
& -m_{f}\left(1-m_{f}\right)(u-\bar{c}) \frac{\partial T}{\partial \bar{c}} \\
& =-m_{f}\left(1-m_{f}\right)(u-\bar{c})\left[m_{d}\left(1-m_{d}\right)-m_{f}\left(1-m_{f}\right)\right]<0
\end{aligned}
$$

Therefore we have

$$
\begin{gathered}
\frac{\partial m d_{F}}{\partial \bar{c}}<0 \\
\frac{\partial m d_{D}}{\partial \bar{c}}=\frac{m_{d}\left(1-m_{d}\right) T-m_{d}\left(1-m_{d}\right) \bar{c} \frac{\partial T}{\partial \bar{c}}}{T^{2}} \\
m_{d}\left(1-m_{d}\right)\left(T-\bar{c} \frac{\partial T}{\partial \bar{c}}\right)=m_{d}\left(1-m_{d}\right)\left[m_{f}\left(1-m_{f}\right) u\right]>0
\end{gathered}
$$

Therefore we have

$$
\frac{\partial m d_{D}}{\partial \bar{c}}>0
$$

(ii) if $\bar{c}<0$

We substitute $\bar{c}=-\bar{b}$ where benefit of using fiat currency $\bar{b}>0$

We note that $m_{f}\left(1-m_{f}\right) u+m_{f}\left(1-m_{f}\right) \bar{b}>0$ and $m_{d}\left(1-m_{d}\right) \bar{b}>0$ 
Let $Q=m_{f}\left(1-m_{f}\right) u+m_{f}\left(1-m_{f}\right) \bar{b}-m_{d}\left(1-m_{d}\right) \bar{b}$

$=m_{f}\left(1-m_{f}\right) u-\left[m_{d}\left(1-m_{d}\right)-m_{f}\left(1-m_{f}\right)\right] \bar{b}$

$\frac{\partial Q}{\partial \bar{b}}=m_{f}\left(1-m_{f}\right)-m_{d}\left(1-m_{d}\right)$

We also note that $m_{d}-m_{f}>0$ and $m_{f}\left(1-m_{f}\right)-m_{d}\left(1-m_{d}\right)=\left(m_{f}-m_{d}\right)\left(1-m_{f}-m_{d}\right)<0$

Then we have

$$
\begin{gathered}
\frac{\partial m d_{F}}{\partial \bar{b}}=\frac{m_{f}\left(1-m_{f}\right) Q-m_{f}\left(1-m_{f}\right)(u+\bar{b}) \frac{\partial Q}{\partial \bar{b}}}{Q^{2}} \\
m_{f}\left(1-m_{f}\right)\left(Q-(u+\bar{b}) \frac{\partial Q}{\partial \bar{b}}\right)=m_{f}\left(1-m_{f}\right)\left[m_{d}\left(1-m_{d}\right) u\right]>0
\end{gathered}
$$

Therefore we have

$$
\frac{\partial m d_{F}}{\partial \bar{b}}>0
$$

Which is equivalent to

$$
\begin{gathered}
\frac{\partial m d_{F}}{\partial \bar{c}}<0 \\
\frac{\partial m d_{D}}{\partial \bar{b}}=\frac{-m_{d}\left(1-m_{d}\right) Q+m_{d}\left(1-m_{d}\right) \bar{b} \frac{\partial Q}{\partial \bar{b}}}{Q^{2}} \\
m_{d}\left(1-m_{d}\right)\left(-Q+\bar{b} \frac{\partial Q}{\partial \bar{b}}\right)=-m_{d}\left(1-m_{d}\right)\left[m_{f}\left(1-m_{f}\right) u\right]<0
\end{gathered}
$$

Therefore we have

$$
\frac{\partial m d_{D}}{\partial \bar{b}}<0
$$

Which is equivalent to

$$
\frac{\partial m d_{D}}{\partial \bar{c}}>0
$$




\section{가상통화는 법정통화를 대체할 수 있는가?}

홍기훈8), 유종민9), 박경훈(10)

최근 비트코인(Bitcoin)이 법정통화(fiat currency)와 함께 통용되면서 법 정통화와 민간발행 가상통화(digital currency) 간 구축(crowding out)효과의 존재 여부 등에 대한 관심이 집중되고 있다. 본고에서는 가상통화에 대한 복 잡한 가정을 전제로 한 기존 연구들과 달리 직관적인 이해가 가능하도록 모형의 가정을 단순화하여 구축효과의 존재 여부 등에 대하여 분석하였다. 본 연구는 Kiyotaki and Wright(1993) 모형의 가정을 보다 단순화하고 법정통화와 민간 발행 가상통화, 두 가지 종류의 통화가 이용되는 경제를 상정하였다. 각 개인 은 가상통화와 법정통화의 사용을 결정하는 데 있어 양자의 상대적 비용과 효 용을 적절히 비교하여 선택한다고 가정하였다. 동 모형을 바탕으로 특정 통화 의 구축이 일어나는지, 아니면 두 통화가 함께 사용되는지를 이론적으로 설명 하고, 어떠한 조건이 통화의 대체를 결정하는지에 대해 분석하였다. 분석 결과, 가상통화가 이용자의 편익측면에서 반드시 법정통화보다 우월하지는 않다는 점에서 가상통화가 법정통화를 대체하지는 않고 두 통화가 함께 사용될 가능 성이 높은 것으로 나타났다. 법정통화와 가상통화가 함께 사용될 가능성이 높다는 점을 감안하여, 가상통화의 사용 증가에 따른 경제적 효과 및 정책적 대응 필요성 등에 대해 지속적으로 연구할 필요가 있다.

핵심 주제어: 비트코인, 가상통화, 이종통화, 구축 효과

JEL Classification: E00, E41, E42

8) 홍익대학교 경영대학 조교수 ( E-mail: hong.jimmy@gmail.com)

9) 홍익대학교 경제학부 조교수 ( E-mail: yucono@hongik.ac.kr)

10) 한국은행 경제연구원 미시제도연구실 부연구위원 ( 전화: 02-880-5481, E-mail: pkhoon@bok.or.kr)

본 연구내용은 집필자의 개인의견이며 한국은행의 공식견해와는 무관합니다. 따라서 본 논문의 내용을 보도하거나 인용할 경우에는 집필자명을 반드시 명시하여 주시기 바랍니다. 


\section{$\mathrm{BOK}$ 경제연구 발간목록}

한국은행 경제연구원에서는 Working Paper인 『BOK 경제연구』 를 수시로 발간하고 있습니다. ${ }^{\circledR B O K}$ 경제연구』 는 주요 경제 현상 및 정책 효과에 대한 직관적 설명 뿐 아니라 깊이 있는 이론 또는 실증 분석을 제공함으로써 엄밀한 논증에 초점을 두는 학술논문 형태의 연구이며 한국은행 직원 및 한국은행 연구용역사업의 연구 결과물이 수록되고 있습니다.

${ }^{『} \mathrm{BOK}$ 경제연구』 는 한국은행 경제연구원 홈페이지(http://imer.bok.or.kr)에서 다운로드하여 보실 수 있습니다.

$\begin{array}{ll}\text { 제2014-1 } & \begin{array}{l}\text { Network Indicators for Monitoring } \\ \text { Intraday Liquidity in BOK-Wire+ }\end{array}\end{array}$

2 중소기업에 대한 신용정책 효과

3 경제충격 효과의 산업간 공행성 분석

4 서비스업 발전을 통한 내외수 균형성장: 기대효과 및 리스크

5 Cross-country-heterogeneous and Time-varying Effects of Unconventional Monetary Policies in AEs on Portfolio Inflows to EMEs

6 인터넷뱅킹, 결제성예금 및 은행 수익성과의 관계 분석

7 Dissecting Foreign Bank Lending Behavior During the 2008-2009 Crisis

8 The Impact of Foreign Banks on Monetary Policy Transmission during the Global Financial Crisis of 2008-2009: Evidence from Korea

9 Welfare Cost of Business Cycles in Economies with Individual Consumption Risk

10 Investor Trading Behavior Around the Time of Geopolitical Risk Events: Evidence from South Korea

11 Imported-Inputs Channel of Exchange Rate Pass-Through: Evidence from Korean Firm-Level Pricing Survey
Seungjin Baek •

Kimmo Soram ki • Jaeho Yoon

정호성·임호성

황선웅·민성환 ·

신동현 · 김기호

김승원 · 황광명

Kyoungsoo Yoon

Christophe Hurlin

이동규·전봉걸

Moon Jung Choi

Eva Gutierrez •

Maria Soledad Martinez Peria

Bang Nam Jeon •

Hosung $\mathrm{Lim} \cdot \mathrm{Ji}$ Wu

Martin Ellison •

Thomas J. Sargent

Young Han Kim •

Hosung Jung

Jae Bin Ahn.

Chang-Gui Park 


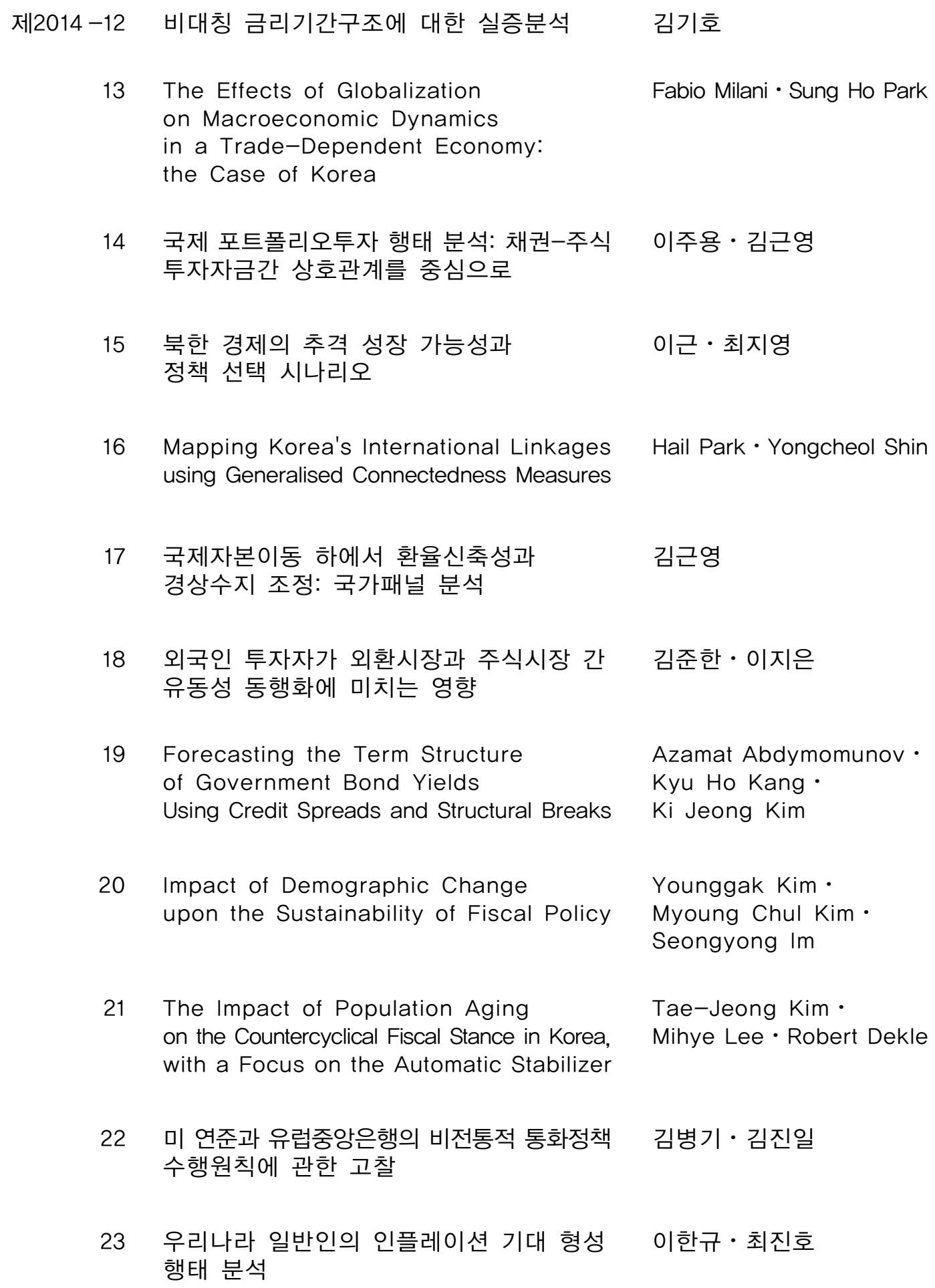

22 미 연준과 유럽중앙은행의 비전통적 통화정책 수행원칙에 관한 고찰

23 우리나라 일반인의 인플레이션 기대 형성 행태 분석

Fabio Milani · Sung Ho Park

이주용·김근영

이근 · 최지영

Hail Park $\cdot$ Yongcheol Shin

김근영

김준한·이지은

Azamat Abdymomunov . Kyu Ho Kang •

$\mathrm{Ki}$ Jeong Kim

Younggak Kim $\cdot$

Myoung Chul Kim.

Seongyong Im

Tae-Jeong Kim •

Mihye Lee $\cdot$ Robert Dekle

김병기·김진일

이한규-최진호 


\section{제2014-24 Nonlinearity in Nexus between Working Hours and Productivity \\ Strategies for Reforming Korea's Labor Market to Foster Growth}

글로벌 금융위기 이후 성장잠재력 확충: 2014 한국은행 국제컨퍼런스 결과보고서

인구구조 변화가 경제성장률에 미치는 영향: 자본이동의 역할에 대한 논의를 중심으로

\section{Safe Assets}

확장된 실업지표를 이용한

우리나라 노동시장에서의 이력현상 분석

Entropy of Global Financial Linkages

International Currencies Past, Present and Future: Two Views from Economic History

금융체제 이행 및 통합 사례:

남북한 금융통합에 대한 시사점

Measuring Price-Level Uncertainty and Instability in the U.S., 1850-2012

고용보호제도가 노동시장 이원화

및 노동생산성에 미치는 영향

해외충격시 외화예금의 역할 : 주요 신흥국 신용스프레드에 미치는 영향을 중심으로

실업률을 고려한 최적 통화정책 분석

우리나라 무역거래의 결제통화 결정요인 분석

Global Liquidity Transmission to

Emerging Market Economies, and Their Policy Responses
Dongyeol Lee $\cdot$

Hyunjoon Lim

Mai Dao - Davide Furceri -

Jisoo Hwang .

Meeyeon Kim •

Tae-Jeong Kim

한국은행 경제연구원

손종칠

Robert J. Barro

김현학·황광명

Daeyup Lee

Barry Eichengreen

김병연

Timothy Cogley •

Thomas J. Sargent

김승원

정호성·우준명

김인수·이명수

황광명 · 김경민 ·

노충식·김미진

Woon Gyu Choi ·

Taesu Kang •

Geun-Young Kim •

Byongju Lee 
제2015-1 글로벌 금융위기 이후 주요국

통화정책 운영체계의 변화

2 미국 장기시장금리 변동이 우리나라 금리기간구조에 미치는 영향 분석 및 정책적 시사점

3 직간접 무역연계성을 통한 해외충격의 우리나라 수출입 파급효과 분석

4 통화정책 효과의 지역적 차이

5 수입중간재의 비용효과를 고려한 환율변동과 수출가격 간의 관계

6 중앙은행의 정책금리 발표가 주식시장 유동성에 미치는 영향

7 은행 건전성지표의 변동요인과 거시건전성 규제의 영향

8 Price Discovery and Foreign Participation in The Republic of Korea's Government Bond Futures and Cash Markets

9 규제가 노동생산성에 미치는 영향: 한국의 산업패널 자료를 이용한 실증분석

10 인구 고령화와 정년연장 연구 (세대 간 중첩모형(OLG)을 이용한 정량 분석)

11 예측조합 및 밀도함수에 의한 소비자물가 상승률 전망

Foreign Ownership, Legal System and Stock Market Liquidity
김병기·김인수

강규호·오형석

최문정·김근영

김기호

김경민

이지은

강종구

Jaehun Choi · Hosung Lim •

Rogelio Jr. Mercado •

Cyn-Young Park

이동렬·최종일·이종한

홍재화·강태수

김현학

우준명

Jung-Min Kim

Hyunju Kang •

Bok-Keun $\mathrm{Yu}$.

Jongmin $\mathrm{Yu}$

Jieun Lee $\cdot$ Kee H. Chung 


\begin{tabular}{|c|c|c|}
\hline 제2015 -16 & $\begin{array}{l}\text { 바젤피 은행 경기대응완충자본 규제의 } \\
\text { 기준지표에 대한 연구 }\end{array}$ & 서현덕·이정연 \\
\hline 17 & 우리나라 대출 수요와 공급의 변동요인 분석 & 강종구·임호성 \\
\hline 18 & 북한 인구구조의 변화 추이와 시사점 & 최지영 \\
\hline 19 & $\begin{array}{l}\text { Entry of Non-financial Firms and Competition } \\
\text { in the Retail Payments Market }\end{array}$ & Jooyong Jun \\
\hline 20 & $\begin{array}{l}\text { Monetary Policy Regime Change } \\
\text { and Regional Inflation Dynamics: } \\
\text { Looking through the Lens of } \\
\text { Sector-Level Data for Korea }\end{array}$ & $\begin{array}{l}\text { Chi-Young Choi } \\
\text { Joo Yong Lee } \\
\text { Roisin O'Sullivan }\end{array}$ \\
\hline 21 & $\begin{array}{l}\text { Costs of Foreign Capital Flows } \\
\text { in Emerging Market Economies: } \\
\text { Unexpected Economic Growth } \\
\text { and Increased Financial Market Volatility }\end{array}$ & $\begin{array}{l}\text { Kyoungsoo Yoon } \\
\text { Jayoung Kim }\end{array}$ \\
\hline 22 & $\begin{array}{l}\text { 글로벌 금리 정상화와 통화정책 과제: } \\
\text { 2015년 한국은행 국제컨퍼런스 결과보고서 }\end{array}$ & 한국은행 경제연구원 \\
\hline 23 & $\begin{array}{l}\text { The Effects of Global Liquidity } \\
\text { on Global Imbalances }\end{array}$ & $\begin{array}{l}\text { Marie-Louise DJIGBENOU-KRE · } \\
\text { Hail Park }\end{array}$ \\
\hline 24 & 실물경기를 고려한 내재 유동성 측정 & 우준명·이지은 \\
\hline 25 & Deflation and Monetary Policy & Barry Eichengreen \\
\hline 26 & $\begin{array}{l}\text { Macroeconomic Shocks } \\
\text { and Dynamics of Labor Markets in Korea }\end{array}$ & $\begin{array}{l}\text { Tae Bong Kim. } \\
\text { Hangyu Lee }\end{array}$ \\
\hline 27 & $\begin{array}{l}\text { Reference Rates and Monetary Policy } \\
\text { Effectiveness in Korea }\end{array}$ & $\begin{array}{l}\text { Heung Soon Jung } \\
\text { Dong Jin Lee } \\
\text { Tae Hyo Gwon } \\
\text { Se Jin Yun }\end{array}$ \\
\hline 28 & Energy Efficiency and Firm Growth & $\begin{array}{l}\text { Bongseok Choi } \\
\text { Wooyoung Park } \\
\text { Bok-Keun Yu }\end{array}$ \\
\hline 29 & $\begin{array}{l}\text { An Analysis of Trade Patterns } \\
\text { in East Asia and the Effects of } \\
\text { the Real Exchange Rate Movements }\end{array}$ & $\begin{array}{l}\text { Moon Jung Choi } \\
\text { Geun-Young Kim } \\
\text { Joo Yong Lee }\end{array}$ \\
\hline 30 & $\begin{array}{l}\text { Forecasting Financial Stress Indices in } \\
\text { Korea: A Factor Model Approach }\end{array}$ & $\begin{array}{l}\text { Hyeongwoo Kim. } \\
\text { Hyun Hak Kim. } \\
\text { Wen Shi }\end{array}$ \\
\hline
\end{tabular}


제2016-1 The Spillover Effects of U.S. Monetary Policy on Emerging Market Economies: Breaks, Asymmetries and Fundamentals

2 Pass-Through of Imported Input Prices to Domestic Producer Prices: Evidence from Sector-Level Data

3 Spillovers from U.S. Unconventional Monetary Policy and Its Normalization to Emerging Markets: A Capital Flow Perspective

4 Stock Returns and Mutual Fund Flows in the Korean Financial Market:

A System Approach

5 정책금리 변동이 성별·세대별 고용률에 미치는 영향

6 From Firm-level Imports to Aggregate Productivity: Evidence from Korean Manufacturing Firms Data

7 자유무역협정(FTA)이 한국 기업의 기업내 무역에 미친 효과

8 The Relation Between Monetary and Macroprudential Policy

9 조세피난처 투자자가 투자 기업 및 주식 시장에 미치는 영향

10 주택실거래 자료를 이용한 주택부문 거시 건전성 정책 효과 분석

11 Does Intra-Regional Trade Matter in Regional Stock Markets?: New Evidence from Asia-Pacific Region

12 Liability, Information, and Anti-fraud Investment in a Layered Retail Payment Structure

Testing the Labor Market Dualism in Korea
Geun-Young Kim •

Hail Park •

Peter Tillmann

JaeBin Ahn •

Chang-Gui Park •

Chanho Park

Sangwon Suh

Byung-Soo Koo

Jaebeom Kim •

Jung-Min Kim

정성엽

JaeBin Ahn •

Moon Jung Choi

전봉걸·김은숙 · 이주용

Jong Ku Kang

정호성·김순호

정호성·이지은

Sei-Wan Kim • Moon Jung Choi

Kyoung-Soo Yoon • Jooyong Jun

Sungyup Chung •

Sunyoung Jung

최지영 비공식부문 분석 


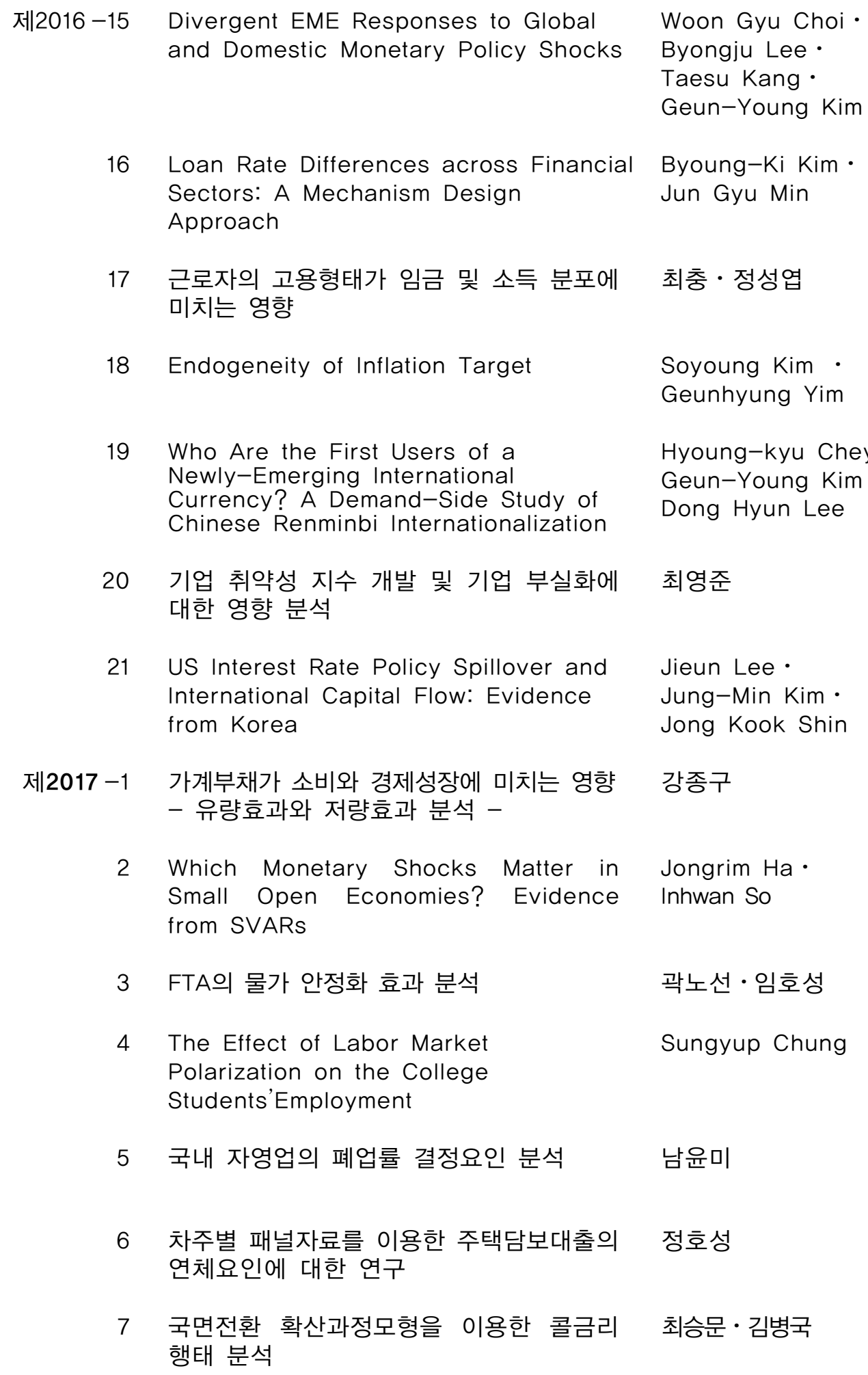

20 기업 취약성 지수 개발 및 기업 부실화에 최영준 대한 영향 분석

21 US Interest Rate Policy Spillover and International Capital Flow: Evidence from Korea

5 국내 자영업의 폐업률 결정요인 분석 남윤미

6 차주별 패널자료를 이용한 주택담보대출의 정호성 연체요인에 대한 연구

7 국면전환 확산과정모형을 이용한 콜금리 최승문·김병국 행태 분석

Sungyup Chung 


\begin{tabular}{|c|c|c|}
\hline 제2017 -8 & $\begin{array}{l}\text { Behavioral Aspects of Household } \\
\text { Portfolio Choice: Effects of Loss } \\
\text { Aversion on Life Insurance Uptake } \\
\text { and Savings }\end{array}$ & In Do Hwang \\
\hline 9 & 신용공급 충격이 재화별 소비에 미치는 영향 & 김광환 · 최석기 \\
\hline 10 & 유가가 손익분기인플레이션에 미치는 영향 & 김진용·김준철·임형준 \\
\hline 11 & $\begin{array}{l}\text { 인구구조변화가 인플레이션의 장기 추세에 } \\
\text { 미치는 영향 }\end{array}$ & 강환구 \\
\hline 12 & $\begin{array}{l}\text { 종합적 상환여건을 반영한 과다부채 } \\
\text { 가계의 리스크 요인 분석 }\end{array}$ & 이동진·한진현 \\
\hline 13 & $\begin{array}{l}\text { Crowding out in a Dual Currency Regime? } \\
\text { Digital versus Fiat Currency }\end{array}$ & $\begin{array}{l}\text { KiHoon Hong } \cdot \\
\text { Kyounghoon Park } \\
\text { Jongmin Yu }\end{array}$ \\
\hline
\end{tabular}

